\title{
Short- and long-term effects of hypophysectomy and unilateral ovariectomy on ovarian follicular populations in sheep
}

\author{
J. Dufour, L. P. Cahill and P. Mauléon \\ I.N.R.A.-Station de Physiologie de la Reproduction, 37380 Nouzilly, France
}

\begin{abstract}
Summary. The effects of hypophysectomy and unilateral ovariectomy on the total number of follicles with $>3$ layers of granulosa cells were determined at 4 and 70 days following treatment.

The population of preantral follicles $(<0.23 \mathrm{~mm}$ diam.) was found to be under the control of gonadotrophins but such control was only evident on a long-term basis. At 70 days after unilateral ovariectomy there was a large increase in the number of preantral follicles but at 70 days after hypophysectomy there was a large decrease.

The population of antral follicles $(>0.23 \mathrm{~mm}$ diam.) was under the immediate control of gonadotrophins. By 4 days after hypophysectomy all large antral follicles had become atretic and the number of antral follicles was further decreased at 70 days after treatment. At 70 days after unilateral ovariectomy there was an increase in the number of antral follicles.

The follicular growth rates at 70 days following treatment were decreased in hypophysectomized ewes but increased in ewes after unilateral ovariectomy.
\end{abstract}

\section{Introduction}

A recent study of folliculogenesis in sheep has demonstrated that breeds with high ovulation rates have more growing follicles than breeds with low ovulation rates (Cahill, Mariana \& Mauléon, 1979). Attempts to modify the pattern of folliculogenesis in sheep have been only partly successful when using exogenous gonadotrophins. The failure of such injections to modify the population of follicles to give a constant level of ovulation rate may be best explained by the short duration of action of exogenous hormones relative to the long duration of folliculogenesis and thus such treatments only stimulate follicles of the largest sizes.

The purpose of the present study was to determine the role of anterior pituitary hormones on folliculogenesis in sheep by studying the effects of hypophysectomy and unilateral ovariectomy which alter the hormonal-ovarian equilibrium in different directions.

\section{Materials and Methods}

\section{Animals}

At their second oestrus following the onset of the breeding season, 10 crossbred ewes $(3 / 4$ Romanov $\times 1 / 4$ Préalpes du Sud) were assigned alternately to be hypophysectomized or serve as controls and were operated upon on Day 10 of that cycle. Hypophysectomy was carried out using the technique previously described by Denamur \& Mauleon (1963). The control ewes were kept under halothane inhalation for a period of time equivalent to that of the hypophysectomy operation (1 h). 
The treatment effect was then determined at two different intervals using one ovary of a ewe at each time. One ovary of the hypophysectomized ewes was removed 4 days after treatment and is called the hypox-short-term (Hs) group. The remaining ovary of the hypophysectomized ewes was then removed 70 days after treatment and termed the hypox-long-term hemicastrated (Hl) group. The control ewes were treated similarly to give the control short-term (Cs) group (ovariectomy 4 days after treatment) and control long-term $(\mathrm{Cl})$ group (ovariectomy 4 cycles, i.e. 70 days, after treatment). The ewes in Groups $\mathrm{Cl}$ and $\mathrm{Hl}$ had undergone unilateral ovariectomy and the effects of hypophysectomy and those of unilateral ovariectomy were therefore studied together. Hypophysectomized ewes were kept for the whole duration of the experiment in a $24^{\circ} \mathrm{C}$ temperature-controlled room. Hypophysectomized ewes were injected with $5 \mathrm{mg}$ cortisone acetate per day on each of 3 consecutive days following hypophysectomy. Tẉo more injections each of $5 \mathrm{mg}$ cortisone acetate/day were injected after unilateral ovariectomy of hypophysectomized ewes.

After ovariectomy, the ovaries were fixed in Bouin-Hollande's solution, serially sectioned at a thickness of $7 \mu \mathrm{m}$ and all sections were mounted and stained with Feulgen's stain.

\section{Follicular populations}

Every section of each ovary was inspected under the light microscope and all follicles with 3 or more layers of granulosa cells were counted and their surface area measured on the section where the nucleolus was found. Follicular area was measured by the technique previously described (Cahill et al., 1979).

Follicles were classified as normal or atretic. An atretic follicle was defined as a follicle with four or more pyknotic bodies on the edge of or among the granulosa cells of the section containing the nucleolus. Included in that class of atretic follicles were follicles with widespread disintegration of the granulosa cells but still containing the oocyte. Atretic follicles in which no oocyte could be found were not considered in this study. A normal follicle was defined as a follicle containing 3 or less pyknotic bodies on the edge of or among the granulosa cells of the section containing the nucleolus.

The area of all growing follicles was measured in $\mu \mathrm{m}^{2}$ and transformed into logarithms. The data were then arranged into classes for statistical analyses. In order to conform with the normal convention of expressing follicular size by a mean diameter, the area of the follicle was then assumed to be circular and the diameter was calculated and expressed in $\mathrm{mm}$.

Follicies were grouped according to the beginning of antrum formation, i.e. preantral and antral follicles. Appearance of the antrum was fixed at a diameter of $0.23 \mathrm{~mm}$ from data previously reported (Cahill et al., 1979).

\section{Mitotic index}

The number of mitotic figures was observed in 3 sections, i.e. on one section either side of and the section containing the nucleolus in the following classes of preantral follicles with diameters of $<0.06,0.06-0.11$ or $0.12-0.22 \mathrm{~mm}$. Fifteen follicles per class per ovary were studied. For antral follicles the classes were for diameters of $0.23-0.35,0.36-0.63$ and $>0.63$ $\mathrm{mm}$. On the section containing the oocyte nucleolus, the number of mitotic figures was counted in 20 different areas of a known volume of granulosa tissue in 10 different follicles per class for each ovary. To determine the number of granulosa cells occupying a known volume of tissue for each of these 3 classes, the number of cells was counted in 10 different areas of 10 different follicles and the mean obtained. For follicles $<0.22 \mathrm{~mm}$ in diameter, the number of cells per follicle size was evaluated. From these data, the proportion of cells undergoing mitosis (mitotic index) was calculated and expressed as a percentage for each class of follicle. 


\section{Statistical methods}

The effect of treatment was tested statistically by an analysis of variance using a split-plot model, the whole unit being the ewes within treatment. The effect of time (short versus long term) was tested within treatments, the ewes within treatment and time being the sub-unit. Class of follicular size was not analysed as a factor because of lack of homogeneity of variance among small and large follicles.

\section{Results}

The overall mean ovulation rate observed at the time of removal of the first ovary was 2.4 . At the removal of the second ovary, the ovulation rate in $\mathrm{Group} \mathrm{Cl}$ was $2 \cdot 2$. No corpora lutea or corpora albicania were observed in ewes in the Hl group.

\section{Follicular populations}

Preantral follicles. The mean number of preantral follicles was significantly lower in Groups $\mathrm{Hs}$ and $\mathrm{Hl}$ than in Groups Cs and $\mathrm{Cl}$ (Text-fig. 1). Ewes in the control groups had 45.0\% more preantral follicles than the hypophysectomized ewes $(P<0.01)$. However, among the unilaterally ovariectomized ewes the effect on the number of preantral follicles differed according to the presence or absence of the pituitary, because in $\mathrm{Group} \mathrm{Cl}$ ewes the mean number of pre-

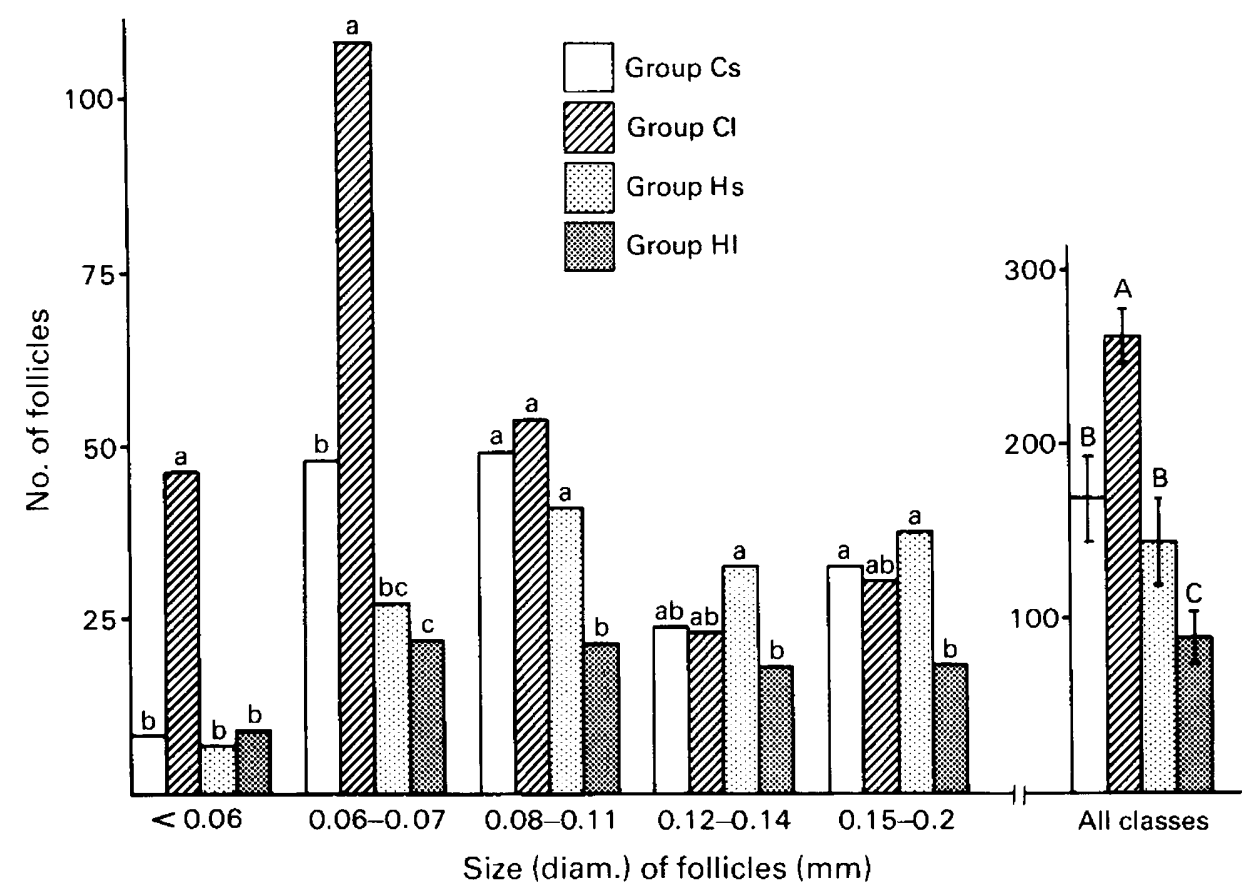

Text-fig. 1. The distribution of the mean number of preantral follicles per size class in ewes (5/ group) of Groups $\mathrm{Cs}, \mathrm{Cl}, \mathrm{Hs}$ and $\mathrm{Hl}$. Within each follicular size, treatment means with different letters $(\mathrm{a}, \mathrm{b}, \mathrm{c})$ are significantly different $(P<0.05)$. The combined values for all classes are given as mean \pm s.e.m., and values which are significantly different $(P<0.05)$ are indicated by different letters (A, B, C). 
antral follicles increased by $61.5 \%$ compared to that for Group Cs, while in Group $\mathrm{Hl}$ it decreased by $61.1 \%$ compared to that in Group Hs $(P<0.01)$. This increase in the mean number of preantral follicles in Group $\mathrm{Hl}$ was greater for the smaller follicles (Text-fig. 1). In the follicular classes of $<0.06 \mathrm{~mm}$ and $0.06-0.07 \mathrm{~mm}$ in diameter, an increase of $467 \%$ and $133 \%$ respectively in the number of follicles was observed in ewes in Group $\mathrm{Cl}$ compared to those in Group Cs $(P<0.01)$. The effect of hypophysectomy, however, was greater in the larger preantral follicles. In follicular classes of $0.08-0.11,0.12-0.15$ and $0.16-0.22 \mathrm{~mm}$, decreases of 48,44 and $51 \%$ respectively were observed in Group $\mathrm{Hl}$ compared to Group Hs.

Therefore the number of preantral follicles increased in Group $\mathrm{Cl}$ ewes mainly for the smaller follicles. In Group $\mathrm{Hl}$ ewes, however, the decrease in the number of preantral follicles was accounted for by the larger follicles.

Antral follicles. The changes in the mean number of normal antral follicles differed in control ewes as compared to hypophysectomized ewes. The mean number of antral follicles increased by $24.5 \%$ in Group $\mathrm{Cl}$ compared to Group Cs while it significantly decreased by $40.6 \%$ in Group $\mathrm{Hl}$ compared to Group Hs (Text-fig. 2).

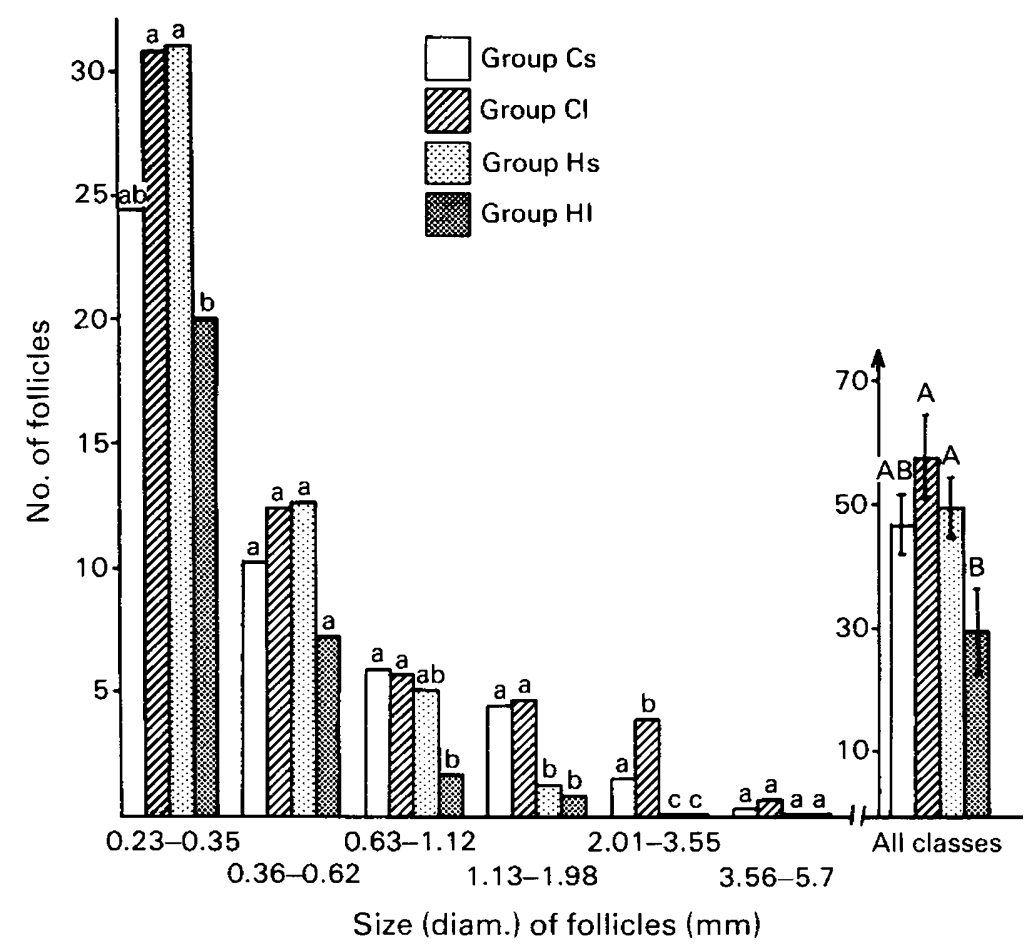

Text-fig. 2. The distribution of the mean number of antral follicles per size class in ewes (5/ group) from Groups $\mathrm{Cs}, \mathrm{Cl}, \mathrm{Hs}$ and $\mathrm{Hl}$. Within each follicular size, treatment means with different letters $(\mathrm{a}, \mathrm{b}, \mathrm{c})$ are significantly different $(P<0.05)$. The combined values for all classes are given as mean \pm s.e.m., and values which are significantly different $(P<0.05)$ are indicated by different letters $(\mathrm{A}, \mathrm{B}, \mathrm{C})$.

The effect of unilateral ovariectomy was most evident in the class of follicles $2.01-3.55 \mathrm{~mm}$ diameter for which Group $\mathrm{Cl}$ ewes had $73.1 \%$ more follicles than did Group Cs ewes. In hypophysectomized ewes even 4 days after treatment (Group Hs) all follicles larger than 2.01 $\mathrm{mm}$ in diameter were affected. For antral follicles smaller than $2.01 \mathrm{~mm}$ in diameter, Group Hl ewes had fewer normal follicles than did Group Hs ewes (Text-fig. 2). The mean ( \pm s.e.m.) diameters of the largest normal follicle per ovary were $2.85 \pm 0.06$ and $3.56 \pm 0.06 \mathrm{~mm}$ in 
Groups $\mathrm{Cs}$ and $\mathrm{Cl}$ and $1.3 \pm 0.05$ and $0.9 \pm 0.19 \mathrm{~mm}$ in Groups $\mathrm{Hs}$ and $\mathrm{Hl}$ respectively (hypox versus control; $P<0.01$ ). The mean diameters of the second largest follicle were 1.79 \pm 0.13 and $2.85 \pm 0.02 \mathrm{~mm}$ in Groups $\mathrm{Cs}$ and $\mathrm{Cl}$ and $0.9 \pm 0.07$ and $0.7 \pm 0.19 \mathrm{~mm}$ in Groups $\mathrm{Hs}$ and $\mathrm{Hl}$ respectively (hypox versus control; $P<0.01$ ). The interaction indicated that while the average diameter of the second largest follicle increased in Group $\mathrm{Cl}$ ewes, it remained about the same in Group $\mathrm{Hl}$ ewes $(P<0.01)$.

Therefore antral follicles increased in number in Group $\mathrm{Cl}$ ewes mainly in the class size of $2.01 \mathrm{~mm}$ in diameter. In hypophysectomized ewes, even after short-term effects, the only follicles observed larger than $2.01 \mathrm{~mm}$ were atretic.

Atretic follicles. No preantral follicles were observed to be atretic in this study. Except for the smallest size class of antral follicles, the mean numbers ( \pm s.e.m.) of normal plus atretic follicles in the five largest classes were similar, being $32 \pm 4,36 \pm 3,34 \pm 4$ and $31 \pm 4$ for Groups Cs, $\mathrm{Cl}$, Hs and $\mathrm{Hl}$ respectively. However, the proportion of atretic follicles differed greatly for the various classes according to the presence or absence of the pituitary gland (Text-fig. 3). In follicle classes of $0.36-0.62,0.63-1.12,1 \cdot 13-1.98$ and 3.56-5.7 mm diameter, Group Cl ewes had $1 \cdot 0,17.4,10 \cdot 4$ and $41.7 \%$ fewer atretic follicles than did Group Cs ewes. In the follicle class 2.01-3.55 mm, Group $\mathrm{Cl}$ ewes had 12.2\% more atretic follicles than did Group Cs ewes. However, since Group $\mathrm{Cl}$ ewes had $77.1 \%$ more follicles of this size than Group Cs ewes, then, despite this difference in the rate of atresia, they still had $73.1 \%$ more normal follicles than did Group Cs ewes (Text-fig. 3).

In hypophysectomized ewes, the proportion of atretic follicles increased with the size of follicles. All follicles greater than $2.01-3.55 \mathrm{~mm}$ were atretic even 4 days after treatment (Group $\mathrm{Hs}$ ). In follicles of the smaller size classes the proportion of atretic follicles was greater in Group Hl. For follicles of $0.36-0.62,0.63-1.12$ and $1.13-1.98 \mathrm{~mm}$ diameter, there were $30.5,35.5$ and $2.7 \%$ respectively more atretic follicles in Group $\mathrm{Hl}$ than in Group Hs ewes (Text-fig. 3).

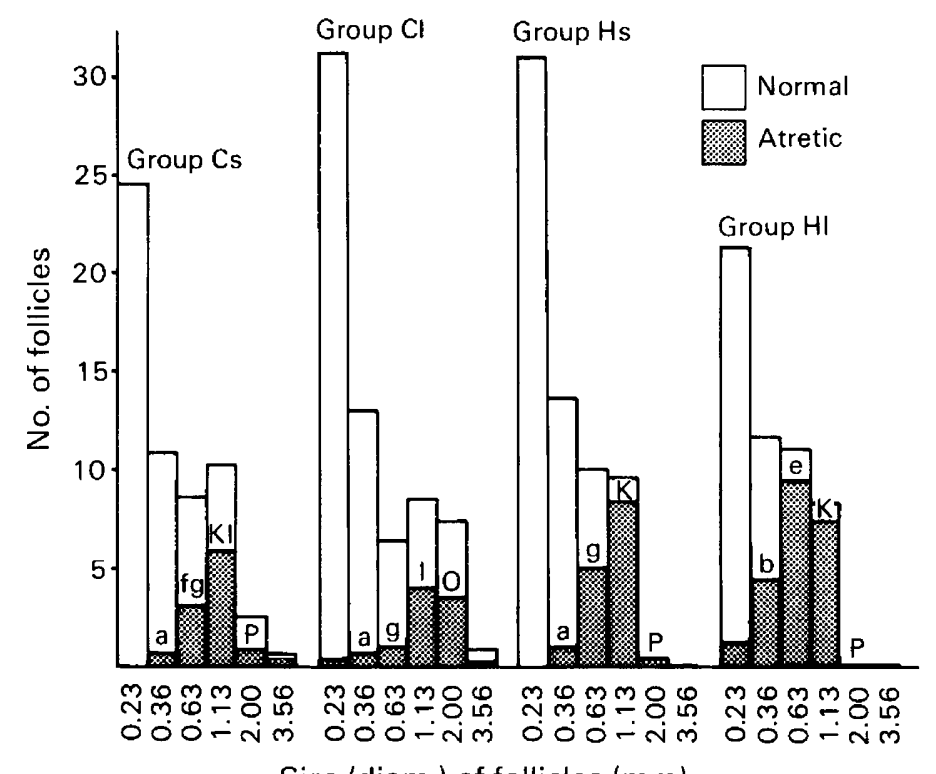

Size (diam.) of follicles $(\mathrm{mm})$

Text-fig. 3. The distribution of the mean number of normal and atretic antral follicles of various size classes in ewes of Groups $\mathrm{Cs}, \mathrm{Cl}, \mathrm{Hs}$ and $\mathrm{Hl}$. Comparisons between treatment of the mean number of atretic follicles in the different groups are made for follicles of similar size. Treatment means with different letters $(\mathrm{a}, \mathrm{b} ; \mathrm{e}, \mathrm{f}, \mathrm{g} ; \mathrm{K}, \mathrm{I}$ and $\mathrm{O}, \mathrm{P}$ for follicular classes $0.36-0.62 ; 0.63-$ $1.12 ; 1.13-1.99$ and $2.0-3.55$ respectively) are significantly different $(P<0.05)$. 
Therefore, the rate of atresia of antral follicles was increased in hypophysectomized ewes, especially among the largest follicles, even after short-term treatment. In Group $\mathrm{Cl}$ ewes, however, the rate of atresia was slightly decreased for antral follicles but this does not explain the increase in the number of the normal largest follicles per ovary.

Mitotic activity of follicles. Three features of the granulosa cells were used to quantify mitotic activity of normal follicles (i) mitotic index, (ii) proportion of follicles in which one mitotic figure was seen (i.e. active follicles) and (iii) the overall number of active follicles (i.e. estimated proportion of active follicles $x$ number of follicles for a given class). To simplify the presentation of results, the follicular population will be considered in two classes only-preantral and antral follicles.

In preantral follicles the mitotic index for the mean of the three classes of follicles was $0 \cdot 18 \pm$ 0.02 in Group $\mathrm{Cl}$ ewes, 0.04 more than in Group Cs ewes (Table 1). In hypophysectomized ewes, however, it was $0.23 \pm 0.04$ in Group Hs ewes, i.e. 0.13 more than in Group $\mathrm{Hl}$ ewes $(P<$ $0.05)$. When the proportion of active follicles was considered in relation to the total number of follicles present in a treatment group (i.e. estimated no. of active follicles), Group $\mathrm{Cl}$ ewes had an estimated $35.3 \%$ more active follicles than did Group $C$ s ewes $(P<0.01)$. However, the estimated number of active follicles was $78.6 \%$ less in Group $\mathrm{Hl}$ ewes than Group Hs ewes $(P<$ 0.01 ). The mean proportion of active preantral follicles did not change between Groups Cs and Cl. However, Group $\mathrm{Hl}$ ewes had $24 \%$ fewer active follicles than Group Hs ewes $(P<0.01)$. The mitotic index for the three classes of antral follicles was $1.69 \pm 0.09$ in Group Cs ewes, 0.28 more than in ewes of Group $\mathrm{Cl}$ (Table 1). However, it was $1.36 \pm 0.10$ in Group Hs ewes, 0.52 more than in Group $\mathrm{Hl}$ ewes $(P<0.01)$.

Table 1. The overall mean ( \pm s.e.m.) mitotic activity of granulosa cells, mean proportion of active follicles studied and the mean estimated number of active follicles for preantral and antral follicles for Groups $\mathrm{Cs}, \mathrm{Cl}, \mathrm{Hs}$ and $\mathrm{Hl}$

\begin{tabular}{|c|c|c|c|c|c|c|}
\hline \multirow[b]{3}{*}{ Groups } & \multicolumn{3}{|c|}{ Preantral follicles } & \multicolumn{3}{|c|}{ Antral follicles } \\
\hline & \multirow[b]{2}{*}{$\begin{array}{l}\text { Mitotic } \\
\text { index }\end{array}$} & \multicolumn{2}{|c|}{ Active follicles } & \multirow[b]{2}{*}{$\begin{array}{l}\text { Mitotic } \\
\text { index }\end{array}$} & \multicolumn{2}{|c|}{ Active follicles } \\
\hline & & $\%$ studied & $\begin{array}{c}\text { Estimated } \\
\text { no. }\end{array}$ & & $\%$ studied & $\begin{array}{c}\text { Estimated } \\
\text { no. }\end{array}$ \\
\hline Cs & $0.14^{\mathrm{ab}} \pm 0.04$ & $23.0^{\mathrm{a}} \pm 5.6$ & $11 \cdot 6^{\mathrm{ab}} \pm 3 \cdot 2$ & $1.69^{\mathrm{a}} \pm 0.09$ & $91.7^{\mathrm{a}} \pm 0.7$ & $15 \cdot 8^{\mathrm{ab}} \pm 1 \cdot 6$ \\
\hline $\mathrm{Cl}$ & $0.18^{\mathrm{ab}} \pm 0.02$ & $25 \cdot 3^{\mathrm{ab}} \pm 1.8$ & $15 \cdot 7^{\mathrm{a}} \pm 3.0$ & $1.41^{\mathrm{a}} \pm 0.08$ & $95 \cdot 1^{\mathrm{a}} \pm 2 \cdot 1$ & $20.7^{a} \pm 2.8$ \\
\hline $\mathrm{Hs}$ & $0.23^{\mathrm{a}} \pm 0.04$ & $39 \cdot 6^{\mathrm{a}} \pm 5 \cdot 6$ & $17 \cdot 3^{a} \pm 2.7$ & $1 \cdot 36^{\mathrm{a}} \pm 0 \cdot 10$ & $84.4^{\mathrm{ab}} \pm 3 \cdot 7$ & $15 \cdot 5^{\mathrm{ab}} \pm 2 \cdot 3$ \\
\hline $\mathrm{Hl}$ & $0.10^{\mathrm{b}} \pm 0.03$ & $14.9^{b} \pm 5.3$ & $3 \cdot 7^{b} \pm 1 \cdot 0$ & $0.84^{b} \pm 0.21$ & $73 \cdot 3^{b} \pm 7 \cdot 2$ & $8 \cdot 5^{b} \pm 2 \cdot 4$ \\
\hline
\end{tabular}

Treatment means with different superscript letters are significantly different $(P<0.05)$.

The overall proportion of active follicles was $93 \%$ in ewes of the control groups, $14 \%$ more than in hypophysectomized ewes $(P<0.05)$.

For the estimated number of active follicles, Group $\mathrm{Cl}$ ewes had an estimated $22.0 \%$ more follicles than Group $\mathrm{Cs}$ ewes while those in Group $\mathrm{Hl}$ had an estimated $48.1 \%$ fewer active follicles than Group Hs ewes (Table $1 ; P<0.05$ ).

Therefore it can be seen that the estimated number of active follicles (proportion of active follicles $\times$ number of follicles per class) gave the most interesting results. For both the preantral and antral follicles long-term treatment increased the estimated number of active follicles following unilateral ovariectomy but this parameter decreased following hypophysectomy.

\section{Discussion}

Our results show that change of the hormonal-ovarian equilibrium results in varied effects on different parts of the follicular population. Some caution needs to be exercised in considering the effect of unilateral ovariectomy because the seasonal influence during the four treatment cycles 
was not measured. However, such a seasonal influence would be small since only a small difference exists in the follicular populations of sheep between mid-anoestrous and mid-oestrous seasons (L. P. Cahill \& P. Mauléon, unpublished data). The hypophysectomized ewes can be considered as animals having very low plasma concentrations of gonadotrophins. Measurements of prolactin following hypophysectomy showed levels at the limit of the sensitivity of the radioimmunoassay (overall mean $0.86 \mathrm{ng} \mathrm{NIH} / \mathrm{ml}$ ). The unilaterally ovariectomized ewes can be considered as sheep which have had their total ovarian follicular population reduced by half resulting in (i) initially higher levels of gonadotrophins from 5.5 to $12 \mathrm{~h}$ after unilateral ovariectomy (Findlay \& Cumming, 1977), (ii) a change of the feed-back effect on the ovary, and (iii) a change of the within-ovary regulation of follicular growth. In the present study, to maintain the hypophysectomized animals in good health, it was necessary to inject them with cortisone, the influence of which on folliculogenesis is unknown.

The present study shows that preantral follicles are under the control of pituitary hormones and that this control mechanism is a very slow process since the effects were only seen 70 days after treatment. The influence of gonadotrophins, especially FSH, on preantral follicles in rodents has previously been shown in the in-vitro study of Ryle (1971), the in-vivo studies of de Reviers \& Mauleon (1972) and the hormone-receptor study of Presl, Pospisil, Figarov \& Krabec (1974). In the long-term treated group two different effects can be seen: firstly a re-stocking of the preantral follicles from the reserve of primordial follicles, and, secondly a depletion of follicles as they leave to enter the antral phase. In Group $\mathrm{Cl}$ this re-stocking effect occurred at a faster rate than the depletion, resulting in an accumulation of follicles, especially of the smaller preantral follicles and probably of all sized preantral follicles with time. However, in the ewes in Group $\mathrm{Hl}$ the depletion of follicles was occurring at a faster rate than the re-stocking effect and there was therefore an overall decrease in the number of preantral follicles, which confirms the work of Ingram (1953).

Peters, Byskov, Himelstein-Braw \& Faber (1975) concluded that, in the mouse after hypophysectomy, growth initiation can occur in the absence of gonadotrophins, but such interpretations may be questionable as complete hypophysectomy, whereby all gonadotrophinproducing cells are destroyed, is rarely obtained surgically, as shown by the immunocytological study of Dubois, de Reviers \& Courot (1971). In the present study the re-stocking effect (if it exists) was occurring at a slower rate than the depletion effect after long-term hypophysectomy and this strongly suggests that gonadotrophins are needed, perhaps indirectly, to maintain quantitatively the normal rate at which follicles enter the growth phase.

The present study also demonstrates the stability of the preantral follicular population in the sheep. Even at 70 days after hypophysectomy no atresia was observed in preantral follicles, follicular growth rates were very slow and the influence of the pituitary on the number of follicles was only evident in the long-term groups. Thus it appears that the preantral follicles may act as a reserve or a buffer between the quiescent primordial follicles and the rapidly growing antral follicles.

The two opposing effects seen in the preantral follicles were also observed in the antral follicles; firstly, a re-stocking from the preantral reserve, especially in the number of the smaller antral follicles as seen in Group $\mathrm{Cl}$ ewes and secondly by a depletion of the larger antral follicles, this time due to atresia as seen in Group $\mathrm{Hl}$ ewes.

The antral follicles, especially those larger than $2.01 \mathrm{~mm}$ diameter, were found to be almost absolutely dependent on gonadotrophins, since within 4 days of hypophysectomy all such follicles had become atretic. This shows that the largest follicles require gonadotrophic support or protection to prevent atresia and that the gonadotrophic regulation of such follicles is almost instantaneous. Findlay \& Cumming (1977) found an increase in FSH secretion only between 5.5 and $12 \mathrm{~h}$ after unilateral ovariectomy but no long-term changes in secretion. This short-term increased secretion is probably related to the short-term requirement of the very large follicles in the remaining ovary to resist atresia and thus maintain the normal ovulation rate per animal, 
after unilateral ovariectomy. This increase in the number of follicles in the remaining ovary in sheep immediately after unilateral ovariectomy has been previously noted by Dufour, Ginther \& Casida (1971).

The effects after unilateral ovariectomy are difficult to evaluate completely since the operation has such a variety of effects on the ovary and feed-back mechanisms. One of the immediate effects of removal of one ovary is a halving of the number of follicles per animal. The compensatory effect to recuperate this loss was observed in Group $\mathrm{Cl}$ ewes which had more preantral, antral and more active follicles per ovary than the Cs group. McLaren (1966) showed that ovulatory compensation was almost immediate after unilateral ovariectomy in the mouse but complete growth compensation, as judged by ovarian weight took 3 months and we would like to extend this and suggest that complete follicular compensation is also a long process, probably paralleling growth compensation in time. Such follicular compensation as shown by McLaren (1966) and Findlay \& Cumming (1977) is not due to an increase in gonadotrophin secretion and thus could involve subtle intra-ovarian changes. This demonstrates that the between-ovary relationship may be able to influence the intra-ovarian situation by some method other than via gonadotrophin secretion.

The effects on follicular growth rates as determined by mitotic indices were most evident in the long term with a decrease in growth rate following hypophysectomy and an increase following unilateral ovariectomy. This suggests that follicular growth rates are also under a longterm control, probably hormonal, as found by de Reviers (1974). Even 70 days after hypophysectomy, both antral and preantral follicles showed some mitotic activity, which agrees with the reports of Paesi (1949) and Nakano, Mizuno, Katayama \& Tojo (1975). In Group Cl ewes which were in the process of re-stocking their supply of preantral follicles, there were more active preantral follicles per ovary than in Group Cs ewes, although the mitotic index did not differ greatly. This agrees with the model presented by Greenwald (1962) in which, for a given class of follicles, there are reserve and active follicles and follicles are brought into the active phase according to the needs of the ovary.

We acknowledge the help of Mr A. Locatelli who performed the surgical operations, Mrs F. Berthelot for the histological preparations and Mr J.-C. Mariana for his support throughout the experiment. J.D. was on study leave from the Centre de Recherches, Lennoxville, Québec, Canada, and L.P.C. was on study leave from Animal Research Institute, Werribee, Victoria, Australia.

\section{References}

Cahill, L.P., Mariana, J.C. \& Mauléon, P. (1979) Total follicular populations in ewes of high and low ovulation rates. J. Reprod. Fert. 55, 26-35.

Denamur, R. \& Mauléon, P. (1963) Effet de l'hypophy. sectomie sur la morphologie et l'histologie du corps jaune des ovins. C.r. hebd. Séanc. Acad. Sci. Paris, D 257, 264-267.

de Reviers, M.M. (1974) Etude quantitative de l'action des hormones gonadotropes hypophysaires sur la population folliculaire de l'ovaire de rate immature: signification biologique du dosage de l'hormone folliculo-stimulante par le test de Steelman \& Pohley. Thèse, Université de Tours.

de Reviers, M.M. \& Mauléon, P. (1972) Effect des hormones gonadotropes sur l'ovaire de rate immature. Annls Biol. anim. Biochim. Biophys. 13, $177-193$.
Dubois, M.P., de Reviers, M.M. \& Courot, M. (1971) Activité gonadotrope de l'éminence médiane après hypophysectomie chez le rat. Etude en immunofluorescence. Expn. anim. 4, 213-226.

Dufour, J., Ginther, O.J. \& Casida, L.E. (1971) Compensatory hypertrophy after unilateral ovariectomy and destruction of follicles in the anoestrous ewes. Proc. Soc. exp. Biol. Med. 138, 1068-1072.

Findlay, J.K. \& Cumming, I.A. (1977) The effect of unilateral ovariectomy on plasma gonadotropin levels, estrus and ovulation rate in sheep. Biol. Reprod. 17, 178-183.

Greenwald, G.S. (1962) Analysis of superovulation in the adult hamster. Endocrinology 71, 378-389.

Ingram, D.L. (1953) The effect of hypophysectomy on the number of oocytes in the adult albino rat. $J$. Endocr. 9, 307-311. 
McLaren, A. (1966) Regulation of ovulation rate after removal of one ovary in mice. Proc. $R$. Soc. $B$. 166, 316-340.

Nakano, R., Mizuno, T., Katayama, K. \& Tojo, S. (1975) Growth of ovarian follicles in rats in the absence of gonadotrophins. J. Reprod. Fert. 45, 545546.

Paesi, FJ.A. (1949) The influence of hypophysectomy and of subsequent treatment with chorionic gonadotrophin on follicles of different sizes in the ovary of the rat. Acta endocr., Copenh. 3, 89-104.
Peters, M., Byskov, A.G., Himelstein-Braw, R. \& Faber, M. (1975) Follicular growth: the basic event in the mouse and human ovary. J. Reprod. Fert. 45, 559566.

Presl, J., Pospisil, J., Figarov, V. \& Krabec, Z. (1974) Stage dependent changes in the binding of iodinated FSH during ovarian follicle maturation in rats. Endocr. Experiment. 8, 291-297.

Ryle, M. (1971) The growth "in-vitro" of mouse ovarian follicles of different sizes in response to purified gonadotrophins. J. Reprod. Fert. 30, 395-405.

Received 17 November 1978 